\title{
Evaluation of a Series of Overdentures Made in a Higher Education Dental Institution in Southern Brazil
}

\author{
Caroline Dillenburg ${ }^{1}$, Letícia C Dogenski ${ }^{2}$, Tainara E Kopper ${ }^{3}$, André W Rosa ${ }^{4}$, Dimas JR Neto ${ }^{5}$, Moisés Z Cardoso ${ }^{6}$,
} Julia Zandoná ${ }^{7}$, Rejane EL Pedro ${ }^{8}$, Micheline S Trentin ${ }^{9}$, Maria SS Linden ${ }^{10}$, João P De Carli ${ }^{11}$

\begin{abstract}
Aim and objective: This study aimed to evaluate the epidemiological profile, oral health self-perception index, and level of satisfaction of users of complete implant-supported overdentures that had been used for at least 1 year and were made at the School of Dentistry of the University of Passo Fundo, Rio Grande do Sul, Brazil (FO/UPF), between 2014 and 2019.

Materials and methods: The sample consisted of 30 patients with overdentures, who were selected from the dental records filed at the institution. Data on general health and the dental implants involved (brand, type of prosthetic connection, number of implants, and additional overdenture retention system) were collected from the medical records. The 30 patients were invited to answer the Oral Health Impact Profile-14 (OHIP-14) and visual analog scale (VAS) questionnaires, and due to the coronavirus disease 2019 pandemic, it was possible to contact 15 patients.

Results: Most of the prostheses studied were mandibular overdentures, and $66.66 \%$ of the cases were retained by the O-ring system. As for the oral health self-perception of the individuals, it was concluded that male patients had a lower mean overall score $(p=0.047)$ and functional domain $(p=0.042)$ in the OHIP-14. The number of implants and the installation arch interfered with functional domain and psychological capacity $(p<0.05)$. The VAS showed that women have greater esthetic satisfaction with prostheses $(p=0.048)$ and that the bar-clip retention system is more satisfactory than the O-ring $(p=0.017)$.

Conclusion: Despite the limitations of overdentures, it was noted that, when properly indicated, they are a viable option for oral rehabilitation on implants.

Clinical significance: Oral rehabilitation well-indicated with overdentures, especially those retained by the bar-clip system, results in an improvement in the patients' quality of life.

Keywords: Dental implants, Edentulous arcade, Implants, Overdenture, Prostheses.

The Journal of Contemporary Dental Practice (2021): 10.5005/jp-journals-10024-3149
\end{abstract}

\section{INTRODUCTION}

The total loss of natural teeth, or edentulism, is one of the most striking problems affecting oral health, resulting from the cumulative effects of oral diseases throughout life, combined with socioeconomic factors that also contribute significantly. ${ }^{1}$ Edentulism is considered a deficiency that affects the quality of life and nutritional aspects and causes morbidity to individuals, considering that related chewing problems predispose to poor intake and malnutrition. Moreover, periodontal diseases as the causes of tooth loss promote chronic inflammation that may be related to lower survival rates. ${ }^{2}$

Harming esthetics and function and being associated with the deterioration of orofacial tissues, such as bone ridges, nerves, and musculature, ${ }^{3}$ edentulism is treated with prosthetic rehabilitation that includes conventional complete dentures, overdentures, and in some cases, fixed complete dentures supported by implants. ${ }^{4}$ The selection criteria will vary for prosthesis retention and stability, phonation, masticatory efficiency, comfort when eating, confidence in intimate situations, satisfaction, and self-esteem. Either way, oral rehabilitation after total or partial tooth loss leads to a significant improvement in the quality of life of patients. ${ }^{3}$

The removable complete prosthesis is the classic therapy for edentulism. Currently, however, this type of rehabilitation is no longer considered the standard treatment due to the diversity of problems resulting from it, especially regarding patient complaints about insufficient ability to grind food, joint problems, psychological tension, and social disability. ${ }^{5}$ Overdentures, in turn, offer advantages, such as improved prosthesis retention and stability; increase in overall
1,3 Faculty of Dentistry, University of Passo Fundo, Passo Fundo, Rio Grande do Sul, Brazil

${ }^{2}$ Post-Graduate Program in Oral Diagnosis, Faculty of Dentistry, Federal University of Santa Catarina, Florianópolis, Santa Catarina, Brazil

4,5Instituto Gaúcho de Pós-Graduação em Odontologia (IGPGO), Caxias do Sul, Rio Grande do Sul, Brazil

${ }^{6}$ Post-Graduate Program in Dentistry, Faculty of Dentistry, University of Passo Fundo, Passo Fundo, Rio Grande do Sul, Brazil

${ }^{7}$ Post-Graduate Program in Dental Materials, Faculty of Dentistry, Federal University of Rio Grande do Sul, Porto Alegre, Rio Grande do Sul, Brazil

${ }^{8}$ Post-Graduate Program in Biomedical Gerontology, Faculty of Medicine, Federal University of Rio Grande do Sul, Porto Alegre, Rio Grande do Sul, Brazil

${ }^{9}$ Department of Periodontics, Faculty of Dentistry, University of Passo Fundo, Passo Fundo, Rio Grande do Sul, Brazil

${ }^{10}$ Department of Implantology, Faculty of Dentistry, University of Passo Fundo, Passo Fundo, Rio Grande do Sul, Brazil

${ }^{11}$ Departments of Oral Medicine and Prosthodontics, Faculty of Dentistry, University of Passo Fundo, Passo Fundo, Rio Grande do Sul, Brazil

Corresponding Author: João P De Carli, Departments of Oral Medicine and Prosthodontics, Faculty of Dentistry, University of Passo Fundo, Passo Fundo, Rio Grande do Sul, Brazil, e-mail: joaodecarli@upf.br

How to cite this article: Dillenburg C, Dogenski LC, Kopper TE, et al. Evaluation of a Series of Overdentures Made in a Higher Education Dental Institution in Southern Brazil. J Contemp Dent Pract 2021;22(7):778-783.

Source of support: Nil

Conflict of interest: None

(c) Jaypee Brothers Medical Publishers. 2021 Open Access This article is distributed under the terms of the Creative Commons Attribution 4.0 International License (https://creativecommons.org/licenses/by-nc/4.0/), which permits unrestricted use, distribution, and non-commercial reproduction in any medium, provided you give appropriate credit to the original author(s) and the source, provide a link to the Creative Commons license, and indicate if changes were made. The Creative Commons Public Domain Dedication waiver (http://creativecommons.org/publicdomain/zero/1.0/) applies to the data made available in this article, unless otherwise stated. 
oral comfort, function, and psychosocial well-being of patients; and a potential decrease in the resorption of residual bone ridges, ${ }^{4,6}$ with high success rates ranging from 94 to $100 \%$. $^{7}$

When planning an overdenture treatment, the number of implants, their length, and distribution should be considered. Moreover, bone quality and shape, as well as the opposite arch, are decisive to select the number of implants to be installed. ${ }^{8}$ Installing two implants is the standard to support a mandibular overdenture in edentulous patients. However, there is a lack of information on the number of implants required for a maxillary prosthesis, and low survival rates have been reported when few implants $(<4)$ were installed in the maxilla to support this treatment. ${ }^{9}$ Therefore, it seems essential to define reproducible treatment protocols that support the experience of individuals and help to establish clear concepts toward evidence-based dentistry. ${ }^{5}$

Contemporary dentistry presents several systems for fixing removable prostheses to dental implants, and prosthetic stability is directly related to these systems. The connection between prosthesis and implant can be provided by bar structures rigidly attached to the implants to secure the overdenture with a clip (bar-clip system) or by systems individually attached to the prosthetic structure, such as the locator, ERA, O-ring, or magnetic systems. The main objective of choosing between the different types of fixation is to provide a more favorable force distribution to implants, guaranteeing fewer maintenance interventions..$^{10,11}$ Besides the biological effects of the interfacial tension transfer, it should also be considered that implant installation increases treatment costs, highlighting the importance of assessing the minimum number required to support the prosthesis and achieve an optimal costbenefit relationship. ${ }^{9}$

Hence, methods of investigating the oral health-related quality of life are used, mainly in the form of questionnaires. The standardized instrument most commonly documented in the literature is the Oral Health Impact Profile-14 (OHIP-14) survey, which consists of several questions about functional limitations; physical pain; psychological discomfort; and physical, psychological, or social disabilities. ${ }^{12}$ The OHIP-14 questionnaire has acceptability, reliability, and validity, and it is a valuable tool to assess the perception of oral health impacts on the well-being of edentulous patients. Other methodological approaches used as ad hoc instruments include the visual analog scale (VAS) and Satisfaction and Denture Complaint questionnaires. ${ }^{4}$

Considering the above, the present study aimed to evaluate the epidemiological profile, oral health self-perception index, and level of satisfaction of users of complete implant-supported overdentures that had been used for at least 1 year and were manufactured in the School of Dentistry of the University of Passo Fundo, Rio Grande do Sul, Brazil (FO/UPF), between 2014 and 2019. The study considered the influence of essential factors for treatment success with the OHIP-14 and the VAS questionnaires.

\section{Materials and Methods}

\section{Study Design and Ethical Aspects}

This pilot study on oral health and satisfaction with implant prostheses was performed at the School of Dentistry of the University of Passo Fundo (FO/UPF), in Passo Fundo, Rio Grande do Sul, Brazil, after the approval by the Ethics Committee in Research of the referred institution ( $N \circ 2.877 .046$ ).

The database of the institution provided the medical records of all patients subjected to oral rehabilitations between 2014 and 2019, with lower and/or upper implant-supported overdentures that had been used for at least 1 year.

\section{Sample}

The sample consisted of 30 patients of both sexes, rehabilitated in the clinics and internships of the FO/UPF. Epidemiological data and information about prostheses and respective implants were collected from the dental records of the patients. Thus, the following items were evaluated: Sex and age-group of the patients, commercial brand, type of implant (external hexagon, internal hexagon, or Morse taper), number of implants used, and the overdenture retention system (O-ring or bar-clip).

Additionally, to assess oral health self-perception and patient satisfaction with their respective rehabilitation treatments, the OHIP-14 and VAS questionnaires were applied. Given the limitations of social isolation or distance imposed by the coronavirus disease 2019 pandemic, such instruments were applied to patients via telephone calls, and only 15 out of the 30 patients included in the study could be contacted. Thus, the epidemiological study involved 30 patients, and the survey of satisfaction and self-perception in oral health involved 15 patients.

The epidemiological study of the medical records included all patients rehabilitated with complete overdentures made and installed at the School of Dentistry of the University of Passo Fundo between 2014 and 2019, that is, prostheses in use for more than 12 months (30 patients). As for the OHIP-14 and VAS questionnaires, all patients who managed to answer the questions via telephone were included (15 patients). Patients who were not located via telephone were excluded from the study.

It is known that the duration of edentulism before prosthetic treatment can also have an impact on patients' satisfaction and self-perception of oral health. However, the methodology of the present study was based on the OHIP-14 questionnaire, which seeks to collect information from patients based on experiences in the last 12 months. ${ }^{13}$ Thus, the inclusion in the study of patients rehabilitated with overdentures for at least 12 months is justified.

\section{Statistical Analysis}

After collecting data from medical records and questionnaires, the results were tabulated in Microsoft Excel $2010^{\mathrm{TM}}$ spreadsheets and evaluated with descriptive statistics and the Mann-Whitney test $(p \leq 0.05)$.

\section{Results}

Table 1 presents the epidemiological data of the 30 patients analyzed in the epidemiological study and their respective implants and overdentures. The average age was 70.53 years, ranging between 48 and 77 years (Table 1).

The results presented in Tables 2 to 5 refer to the OHIP-14 and VAS questionnaires and include the data from only 15 patients who could be contacted via telephone due to the pandemic, as explained in the methodology session.

When relating the data from the OHIP-14 scale for patients' sex, women presented disadvantages in overall score $(p=0.047)$ and functional domain $(p=0.042)$. Individuals with overdentures in the upper arch had a disadvantage relative to the overall OHIP-14 score $(p=0.037)$, functional domain $(p=0.041)$, and psychological disability $(p=0.034)$ (Table 2 ).

The individuals with Morse taper implants had a disadvantage relative to physical pain when compared to individuals with external hexagon implants $(p=0.044)$. Patients with prostheses retained by the O-ring had worse results than patients with the bar-clip retention system $(p=0.039)$ (Table 3 ). 
Table 1: Characteristics of patients, implants, and prostheses

\begin{tabular}{|c|c|c|}
\hline Variables & $n$ & $\%$ \\
\hline \multicolumn{3}{|l|}{ Age } \\
\hline $41-50$ years & 1 & 3.33 \\
\hline $51-60$ years & 5 & 16.66 \\
\hline $61-70$ years & 11 & 36.66 \\
\hline $71-80$ years & 13 & 43.33 \\
\hline \multicolumn{3}{|l|}{ Sex } \\
\hline Male & 17 & 56.66 \\
\hline Female & 13 & 43.33 \\
\hline \multicolumn{3}{|l|}{ Installation arch } \\
\hline Upper & 8 & 26.66 \\
\hline Lower & 22 & 73.33 \\
\hline \multicolumn{3}{|l|}{ Number of implants } \\
\hline 2 & 16 & 53.33 \\
\hline 4 & 14 & 46.66 \\
\hline \multicolumn{3}{|l|}{ Year of implant installation } \\
\hline 2014 & 7 & 23.33 \\
\hline 2015 & 7 & 23.33 \\
\hline 2016 & 5 & 16.66 \\
\hline 2017 & 8 & 26.66 \\
\hline 2018 & 3 & 10 \\
\hline \multicolumn{3}{|l|}{ Year of prosthesis installation } \\
\hline 2014 & 5 & 16.66 \\
\hline 2015 & 5 & 16.66 \\
\hline 2016 & 5 & 16.66 \\
\hline 2017 & 3 & 10 \\
\hline 2018 & 7 & 23.33 \\
\hline 2019 & 5 & 16.66 \\
\hline \multicolumn{3}{|l|}{ Implant brand } \\
\hline Neodent $^{\mathrm{TM}}$ & 7 & 23.33 \\
\hline Conexão $^{\mathrm{TM}}$ prosthesis system & 10 & 33.33 \\
\hline Signo vinces ${ }^{\mathrm{TM}}$ & 10 & 33.33 \\
\hline SIN ${ }^{\mathrm{TM}}$ implant system & 3 & 10 \\
\hline \multicolumn{3}{|l|}{ Implant type } \\
\hline External hexagon & 14 & 46.66 \\
\hline Morse taper & 16 & 53.33 \\
\hline \multicolumn{3}{|l|}{ Prosthesis retention system } \\
\hline Bar-clip & 10 & 33.33 \\
\hline O-ring & 20 & 66.66 \\
\hline \multicolumn{3}{|l|}{ Overdenture antagonist } \\
\hline Complete denture & 17 & 56.66 \\
\hline Removable partial denture & 4 & 13.33 \\
\hline Overdenture & 1 & 3.33 \\
\hline Fixed complete prosthesis & 1 & 3.33 \\
\hline Natural dentition & 7 & 23.33 \\
\hline
\end{tabular}

There was no statistically significant relationship when comparing the antagonistic arcade type of the overdentures. Patients with four implants had worse results for overall score results $(p=0.048)$, functional domain $(p=0.019)$, and psychological disability $(p=0.047)$ when compared to individuals with two implants (Table 4).

Female patients had greater esthetic satisfaction $(p=0.048)$ with the prostheses than male patients. Additionally, the prostheses with the bar-clip retention system showed greater patient satisfaction than prostheses equipped with the O-ring system $(p=0.017)$ (Table 5).

\section{Discussion}

The high incidence of tooth loss is a reality for the Brazilian population. Cardoso et al., ${ }^{14}$ when performing projections of edentulism in Brazil, observed that by 2040 the number of edentulous arches will decrease, approaching 616,000, while the number of elderly people will increase alarmingly, reaching more than 64 million. Given the data aforementioned, implant-supported prostheses are increasingly becoming a viable alternative. Thus, the present study aimed to assess the self-perception of oral health conditions and the satisfaction index of a series of patients rehabilitated with implant-supported dental prostheses installed at the FO/UPF between 2014 and 2019, considering variables such as sex, age, type of retention system, number of implants, time, and installation arch.

The 2010 National Oral Health Survey performed in Brazil revealed that more than $50 \%$ of the elderly population aged between 65 and 74 years was edentulous and that edentulism was more prevalent among women, especially those with lower income and level of education. ${ }^{1}$ Regarding sex, however, men represented the majority of the sample of the present study $(56.66 \%)$. The prevalent age of individuals was over 60 years, which corroborates the study by Rignon-Breg et al., ${ }^{15}$ who evaluated 80 overdenture users and found the highest percentage of patients in the agegroup of 65 to 80 years. This result can be explained by the increase in edentulism with age, as the elderly population experiences more tooth extractions throughout their lives. ${ }^{14}$

The results obtained with the application of the VAS showed that female patients had greater esthetic satisfaction than male patients. Other significant results obtained with the application of the OHIP-14 questionnaire in the present study showed that female patients had lower functional domain than male patients. Kaufmann et al. ${ }^{16}$ correlated this to the natural tendency of physiological resorption of female maxillaries relative to male ones, which would cause more complex cases of prosthetic rehabilitation in women and promote greater dissatisfaction, mainly in the stability and function of prostheses.

Regarding the prosthesis installation arch, most (73.33\%) were installed in the mandible. A study by Preciado et al. ${ }^{17}$ obtained similar results to the present study, with the majority (64.85\%) of overdentures installed in the lower arch. According to Kronström et al., ${ }^{18}$ it is agreed that mandibular overdentures provide a significant improvement in stability and retention, oral function, and psychological well-being. However, the rehabilitation treatment for maxillary overdentures is more complex and challenging because it involves several factors such as bone quantity and quality suitable for implants, which obtain higher failure rates in this arch, as well as esthetic considerations, phonetics, and oral comfort.

As for the number of implants installed, most patients had two. This result adds to that of Karabach et al., ${ }^{19}$ who evaluated the quality of life of 30 patients rehabilitated with mandibular overdentures, noting that most of them had two implants. Turker and Buyukkaplan ${ }^{11}$ compared stress distributions in implants, abutments, and bone caused by different types of overdenture fixations under functional masticatory forces, verifying that the loads on overdentures supported by two implants are transmitted to the bone tissue through the implants and soft tissues, where 
Evaluation of a Series of Overdentures in Southern Brazil

Table 2: Sex of patients and prosthesis installation arch X OHIP-14 results

\begin{tabular}{|c|c|c|c|c|c|c|c|c|c|c|}
\hline \multirow[b]{2}{*}{ Sex } & \multirow[b]{2}{*}{$n$} & & \multirow[b]{2}{*}{$\begin{array}{l}\text { Overall } \\
\text { score }\end{array}$} & \multicolumn{7}{|c|}{ Variables } \\
\hline & & & & $\begin{array}{c}\text { Functional } \\
\text { domain }\end{array}$ & $\begin{array}{l}\text { Physical } \\
\text { pain }\end{array}$ & $\begin{array}{c}\text { Psychological } \\
\text { discomfort }\end{array}$ & $\begin{array}{l}\text { Physical } \\
\text { disability }\end{array}$ & $\begin{array}{c}\text { Psychological } \\
\text { disability }\end{array}$ & $\begin{array}{c}\text { Social } \\
\text { disability }\end{array}$ & $\begin{array}{c}\text { Social } \\
\text { disadvantage }\end{array}$ \\
\hline \multirow[t]{3}{*}{ Male } & 8 & Mean & 3.75 & 1.75 & 0.75 & 0.37 & 0.50 & 1.37 & 0.25 & 0.50 \\
\hline & & $\begin{array}{l}\text { Standard } \\
\text { deviation }\end{array}$ & 2.12 & 0.70 & 0.70 & 0.51 & 0.92 & 0.91 & 0.46 & 0.53 \\
\hline & & $p$-value & & & & & & & & \\
\hline \multirow[t]{3}{*}{ Female } & 7 & Mean & 6.14 & 2.57 & 1.14 & 1.14 & 0.71 & 0.71 & 0.42 & 0.71 \\
\hline & & $\begin{array}{l}\text { Standard } \\
\text { deviation }\end{array}$ & 6.59 & 0.97 & 1.46 & 1.86 & 1.49 & 1.49 & 0.78 & 0.75 \\
\hline & & $p$-value & 0.047 & 0.042 & 0.510 & 0.282 & 0.740 & 0.229 & 0.595 & 0.533 \\
\hline Arch & $n$ & & $\begin{array}{l}\text { Overall } \\
\text { score }\end{array}$ & $\begin{array}{c}\text { Functional } \\
\text { domain }\end{array}$ & $\begin{array}{l}\text { Physical } \\
\text { pain }\end{array}$ & $\begin{array}{c}\text { Psychological } \\
\text { discomfort }\end{array}$ & $\begin{array}{l}\text { Physical } \\
\text { disability }\end{array}$ & $\begin{array}{c}\text { Psychological } \\
\text { disability }\end{array}$ & $\begin{array}{c}\text { Social } \\
\text { disability }\end{array}$ & $\begin{array}{c}\text { Social } \\
\text { disadvantage }\end{array}$ \\
\hline \multirow[t]{3}{*}{ Upper } & 5 & Mean & 7.6 & 2.80 & 1.20 & 1.40 & 1.00 & 2.40 & 0.60 & 1.00 \\
\hline & & $\begin{array}{l}\text { Standard } \\
\text { deviation }\end{array}$ & 7.5 & 1.60 & 1.64 & 2.07 & 1.73 & 0.89 & 0.89 & 0.70 \\
\hline & & $p$-value & & & & & & & & \\
\hline \multirow[t]{3}{*}{ Lower } & 10 & Mean & 3.5 & 1.80 & 0.80 & 0.40 & 0.40 & 1.30 & 0.20 & 0.40 \\
\hline & & $\begin{array}{l}\text { Standard } \\
\text { deviation }\end{array}$ & 1.9 & 0.63 & 0.78 & 0.69 & 0.84 & 0.82 & 0.42 & 0.51 \\
\hline & & $p$-value & 0.037 & 0.041 & 0.527 & 0.180 & 0.374 & 0.034 & 0.251 & 0.082 \\
\hline
\end{tabular}

Table 3: Implant platform type and prosthesis retention system X OHIP-14 results

\begin{tabular}{|c|c|c|c|c|c|c|c|c|c|c|}
\hline & & & & & & & Variables & & & \\
\hline $\begin{array}{l}\text { Implant } \\
\text { platform }\end{array}$ & $n$ & & $\begin{array}{l}\text { Overall } \\
\text { score }\end{array}$ & $\begin{array}{c}\text { Functional } \\
\text { domain }\end{array}$ & $\begin{array}{l}\text { Physical } \\
\text { pain }\end{array}$ & $\begin{array}{l}\text { Psychological } \\
\text { discomfort }\end{array}$ & $\begin{array}{l}\text { Physical } \\
\text { disability }\end{array}$ & $\begin{array}{c}\text { Psychological } \\
\text { disability }\end{array}$ & $\begin{array}{c}\text { Social } \\
\text { disability }\end{array}$ & $\begin{array}{c}\text { Social } \\
\text { disadvantage }\end{array}$ \\
\hline \multirow{3}{*}{$\begin{array}{l}\text { External } \\
\text { hexagon }\end{array}$} & \multirow[t]{3}{*}{6} & Mean & 3.33 & 2.00 & 0.33 & 0.50 & 0.50 & 1.16 & 0.33 & 0.50 \\
\hline & & $\begin{array}{l}\text { Standard } \\
\text { deviation }\end{array}$ & 1.36 & 1.09 & 0.51 & 0.54 & 0.83 & 0.98 & 0.51 & 0.54 \\
\hline & & $p$-value & & & & & & & & \\
\hline \multirow{3}{*}{$\begin{array}{l}\text { Morse } \\
\text { taper }\end{array}$} & \multirow[t]{3}{*}{9} & Mean & 5.88 & 2.22 & 1.33 & 0.88 & 0.66 & 2.00 & 0.33 & 0.66 \\
\hline & & $\begin{array}{l}\text { Standard } \\
\text { deviation }\end{array}$ & 5.92 & 0.83 & 1.22 & 1.69 & 1.41 & 0.86 & 0.70 & 0.70 \\
\hline & & $p$-value & 0.224 & 0.662 & 0.044 & 0.599 & 0.800 & 0.107 & 1.000 & 0.635 \\
\hline $\begin{array}{l}\text { Retention } \\
\text { system }\end{array}$ & $n$ & & $\begin{array}{l}\text { Overall } \\
\text { score }\end{array}$ & $\begin{array}{c}\text { Functional } \\
\text { domain }\end{array}$ & $\begin{array}{l}\text { Physical } \\
\text { pain }\end{array}$ & $\begin{array}{l}\text { Psychological } \\
\text { discomfort }\end{array}$ & $\begin{array}{l}\text { Physical } \\
\text { disability }\end{array}$ & $\begin{array}{c}\text { Psychological } \\
\text { disability }\end{array}$ & $\begin{array}{c}\text { Social } \\
\text { disability }\end{array}$ & $\begin{array}{c}\text { Social } \\
\text { disadvantage }\end{array}$ \\
\hline \multirow[t]{3}{*}{ Bar-clip } & 6 & Mean & 5.66 & 2.44 & 0.88 & 0.88 & 0.77 & 1.88 & 0.44 & 0.77 \\
\hline & & $\begin{array}{l}\text { Standard } \\
\text { deviation }\end{array}$ & 5.78 & 1.01 & 1.26 & 1.61 & 1.39 & 1.05 & 0.72 & 0.66 \\
\hline & & $p$-value & & & & & & & & \\
\hline \multirow[t]{3}{*}{ O-ring } & 9 & Mean & 3.66 & 1.66 & 1.00 & 0.50 & 0.33 & 1.33 & 0.16 & 0.33 \\
\hline & & $\begin{array}{l}\text { Standard } \\
\text { deviation }\end{array}$ & 2.50 & 0.51 & 0.89 & 0.83 & 0.81 & 0.81 & 0.41 & 0.51 \\
\hline & & $p$-value & 0.443 & 0.039 & 0.856 & 0.599 & 0.497 & 0.297 & 0.413 & 0.192 \\
\hline
\end{tabular}

the prosthetic base is located. Although much higher loads are applied to these implants, usually the reason for the formation of lower stresses in the parts is that most of these loads are transferred to the supporting tissues (fibro mucosal) through the base of the prosthesis. The evaluation of the tensions transmitted to the implant and bone showed that these values were much lower than the resistance limit of both. This may explain the reason why patients with overdentures retained by four implants obtained worse results for functional domain and psychological incapacity than individuals with only two implants.

In this study, most patients (66.66\%) used the O-ring prosthetic fixation system. However, this retention system obtained the worst functional domain in the OHIP-14 questionnaire and the lowest satisfaction in the VAS. This result adds to that of Cune et al., ${ }^{20}$ who evaluated 18 users of mandibular and maxillary overdentures and noticed greater stability, retention, and 
Table 4: Overdenture antagonists and number of implants $X$ OHIP-14 results

\begin{tabular}{|c|c|c|c|c|c|c|c|c|c|c|}
\hline \multirow[b]{2}{*}{ Antagonist } & \multirow[b]{2}{*}{$n$} & & \multirow[b]{2}{*}{$\begin{array}{l}\text { Overall } \\
\text { score }\end{array}$} & \multicolumn{7}{|c|}{ Variables } \\
\hline & & & & $\begin{array}{l}\text { Functional } \\
\text { domain }\end{array}$ & $\begin{array}{l}\text { Physical } \\
\text { pain }\end{array}$ & $\begin{array}{l}\text { Psychological } \\
\text { discomfort }\end{array}$ & $\begin{array}{l}\text { Physical } \\
\text { disability }\end{array}$ & $\begin{array}{c}\text { Psychological } \\
\text { disability }\end{array}$ & $\begin{array}{c}\text { Social } \\
\text { disability }\end{array}$ & $\begin{array}{c}\text { Social } \\
\text { disadvantage }\end{array}$ \\
\hline \multirow{3}{*}{$\begin{array}{l}\text { Natural } \\
\text { teeth }\end{array}$} & 5 & Mean & 3.80 & 2.22 & 1.00 & 0.40 & 0.40 & 1.20 & 0.20 & 0.60 \\
\hline & & $\begin{array}{l}\text { Standard } \\
\text { deviation }\end{array}$ & 2.58 & 1.09 & 1.00 & 0.54 & 0.89 & 0.83 & 0.44 & 0.54 \\
\hline & & $p$-value & & & & & & & & \\
\hline \multirow{3}{*}{$\begin{array}{l}\text { Conventional } \\
\text { dentures }\end{array}$} & 10 & Mean & 5.40 & 2.10 & 0.90 & 0.90 & 0.70 & 1.90 & 0.40 & 0.60 \\
\hline & & $\begin{array}{l}\text { Standard } \\
\text { deviation }\end{array}$ & 5.56 & 0.87 & 1.19 & 1.59 & 1.33 & 0.99 & 0.69 & 0.69 \\
\hline & & $p$-value & 0.557 & 0.850 & 0.875 & 0.514 & 0.660 & 0.201 & 0.574 & 1.000 \\
\hline $\begin{array}{l}\text { Number of } \\
\text { implants }\end{array}$ & $n$ & & $\begin{array}{l}\text { Overall } \\
\text { score }\end{array}$ & $\begin{array}{l}\text { Functional } \\
\text { domain }\end{array}$ & $\begin{array}{l}\text { Physical } \\
\text { pain }\end{array}$ & $\begin{array}{l}\text { Psychological } \\
\text { discomfort }\end{array}$ & $\begin{array}{l}\text { Physical } \\
\text { disability }\end{array}$ & $\begin{array}{c}\text { Psychological } \\
\text { disability }\end{array}$ & $\begin{array}{c}\text { Social } \\
\text { disability }\end{array}$ & $\begin{array}{c}\text { Social } \\
\text { disadvantage }\end{array}$ \\
\hline \multirow[t]{3}{*}{ Two implants } & 7 & Mean & 2.85 & 1.57 & 0.42 & 0.42 & 0.28 & 1.14 & 0.14 & 0.42 \\
\hline & & $\begin{array}{l}\text { Standard } \\
\text { deviation }\end{array}$ & 1.21 & 0.53 & 0.53 & 0.78 & 0.75 & 0.89 & 0.37 & 0.53 \\
\hline & & $p$-value & & & & & & & & \\
\hline \multirow{3}{*}{$\begin{array}{l}\text { Four } \\
\text { implants }\end{array}$} & 8 & Mean & 6.62 & 2.62 & 1.37 & 1.00 & 0.87 & 2.12 & 0.50 & 0.75 \\
\hline & & $\begin{array}{l}\text { Standard } \\
\text { deviation }\end{array}$ & 5.99 & 0.92 & 1.30 & 1.69 & 1.45 & 0.83 & 0.75 & 0.70 \\
\hline & & $p$-value & 0.048 & 0.019 & 0.097 & 0.428 & 0.355 & 0.047 & 0.279 & 0.345 \\
\hline
\end{tabular}

Table 5: Relationships between patient sex and esthetic satisfaction and between the retention system and patient satisfaction according to the VAS results

\begin{tabular}{lcc}
\hline & \multicolumn{2}{c}{ Esthetic satisfaction } \\
\cline { 2 - 3 } Sex & \multicolumn{1}{c}{ Mean (SD) } & $P$ \\
\hline Male & $8.25(0.46)$ & 0.048 \\
Female & $7.71(0.48)$ & \\
\hline & \multicolumn{2}{c}{ Satisfaction with the prosthesis } \\
\cline { 2 - 3 } Retention system & Mean (SD) & $P$ \\
\hline O-ring & $0.77(2.33)$ & 0.017 \\
Bar-clip & $5.33(4.17)$ & \\
\hline
\end{tabular}

satisfaction reported by users of the bar-clip system (10/18), followed by the spherical system (7/18), and the magnetic system $(1 / 10)$. One of the disadvantages of the O-ring system is that the sealing rings require maintenance more often than other types of systems, such as the bar-clip, due to the wear of the polymeric O-ring component, which needs to be replaced to maintain prosthesis retention. ${ }^{21}$

It was also noted a statistically significant relationship between the prosthesis installation arch and functional domain and the psychological disability of patients. Users of maxillary overdentures showed lower functional domain and greater psychological disability than patients with mandibular overdentures. According to Dudley, ${ }^{22}$ the treatment with maxillary implants is more challenging than with mandibular ones due to factors such as esthetic considerations, phonetics, and oral comfort. The results found in the OHIP-14 questionnaire regarding overdenture antagonists did not show statistically significant differences between "natural dentition" and "conventional prostheses" in any of the items evaluated.
However, the complete prosthesis was the antagonist most found, which can be explained by the fact that these prostheses are mostly used among the population over 60 years old.

As for the type of implant, individuals with Morse taper implants had disadvantages relative to physical pain when compared to individuals with external hexagon implants. Although the literature states that the Morse taper system transfers force more adequately to the peri-implant bone, the present investigation suggests that users of overdentures retained by this type of implant have felt a higher pain index in the OHIP-14 questionnaire than users of external hexagon implants, due to the deeper positioning of Morse taper implants in the peri-implant tissues. This deeper position, despite being beneficial in the biomechanical sense, may hinder the installation of prosthetic abutments, mainly O-ring ones, and produce exacerbated symptoms.

As can be seen in the results of the present study, the patients evaluated regarding the satisfaction of the prostheses and selfperception in oral health did not have the same number of implants. In addition, the brand of the implants, their platform, and the type of retention system used were different, as well as there was a diversity of patient sex and prosthesis installation arch. Such variables may explain the differences obtained in the responses to the OHIP-14 and VAS questionnaires. The duration of edentulism before prosthetic treatment can also have an impact on the satisfaction index. This study does not have access to this data, but care has been taken to include only edentulous individuals in the research who have used the same overdentures for at least 1 year.

The sample size for the OHIP-14 and VAS questionnaires of only 15 patients should be considered a limitation of the present study, which does not invalidate the results obtained because the inclusion and exclusion criteria were strictly followed. Thus, further studies on oral health self-perception and the satisfaction of overdenture users are suggested. 


\section{CONCLUSION}

The results obtained with the sample studied allow concluding that female patients had a lower functional domain and greater esthetic satisfaction with the prostheses. Mandibular overdentures retained by the bar-clip system and coupled to only two implants showed better results of oral health self-perception or patient satisfaction. Both tests used (OHIP-14 and VAS) showed the same sensitivity, allowing the achievement of convergent results. Thus, despite the limitations of overdentures, it was noted that, when properly indicated, they are a viable option for oral rehabilitation on implants.

\section{Clinical Significance}

Oral rehabilitation well-indicated with overdentures, especially those retained by the bar-clip system, results in an improvement in the patients' quality of life.

\section{References}

1. Roberto LL, Crespo TS, Monteiro-Junior RS, et al. Sociodemographic determinants of edentulism in the elderly population: a systematic review and meta-analysis. Gerodontology 2019;36(4):325-337. DOI: 10.1111/ger.12430.

2. Oliveira EJP, Alves LC, Santos JLF, et al. Edentulism and all-cause mortality among Brazilian older adults: 11-years follow-up. Braz Oral Res 2020;34:e046. DOI: 10.1590/1807-3107bor-2020.vol34.0046.

3. Gupta A, Felton DA, Jemt T, et al. Rehabilitation of edentulism and mortality: a systematic review. J Prosthodont 2019;28(5):526-535. DOI: 10.1111/jopr.12792.

4. Kutkut A, Bertoli E, Frazer R, et al. A systematic review of studies comparing conventional complete denture and implant retained overdenture. J Prosthodont Res 2018;62(1):1-9. DOI: 10.1016/j.jpor. 2017.06.004.

5. Kern JS, Kern T, Wolfart S, et al. A systematic review and metaanalysis of removable and fixed implant-supported prostheses in edentulous jaws: post-loading implant loss. Clin Oral Implants Res 2016;27(2):174-195. DOI: 10.1111/clr.12531.

6. Nogueira TE, Dias DR, Leles CR. Mandibular complete denture versus single-implant overdenture: a systematic review of patient-reported outcomes. J Oral Rehabil 2017;44(12):1004-1016. DOI: 10.1111/joor.12550.

7. El-Wegoud MA, Fayyad A, Kaddah A, et al. Bar versus ball attachments for implant-supported overdentures in complete edentulism: a systematic review. Clin Implant Dent Relat Res 2018;20(2):243-250. DOI: 10.1111/cid.12551.

8. Di Francesco F, De Marco G, Gironi Carnevale UA, et al. The number of implants required to support a maxillary overdenture: a systematic review and meta-analysis. J Prosthodont Res 2019;63(1):15-24. DOI: 10.1016/j.jpor.2018.08.006.
9. Guenin C, Martín-Cabezas R. How many implants are necessary to stabilise an implant-supported maxillary overdenture? Evid Based Dent 2020;21(1):28-29. DOI: 10.1038/s41432-020-0077-7.

10. Leão RS, Moraes SLD, Vasconcelos BCE, et al. Splinted and unsplinted overdenture attachment systems: a systematic review andmetaanalysis. J Oral Rehabil 2018;45(8):647-656. DOI: 10.1111/joor.12651.

11. Turker N, Buyukkaplan US. Effects of overdenture attachment systems with different working principles on stress transmission: a three-dimensional finite element study. J Adv Prosthodont 2020;12(6):351-360. DOI: 10.4047/jap.2020.12.6.351.

12. Zhang L, Lyu C, Shang Z, et al. Quality of life of implant-supported overdenture and conventional complete denture in restoring the edentulous mandible: a systematic review. Implant Dent 2017;26(6):945-950. DOI: 10.1097/ID.0000000000000668.

13. Slade GD, Spencer AJ. Development and evaluation of the oral health impact profile. Community Dental Health 1994;11(1):3-11. PMID: 8193981.

14. Cardoso M, Balducci I, Telles Dde M, et al. Edentulism in Brazil: trends, projections and expectations until 2040. Cien Saude Colet 2016;21(4):1239-1246. DOI: 10.1590/1413-81232015214.13672015.

15. Rignon-Bret C, Wulfman C, Hadida A, et al. Immediate loading of two unsplinted implants in edentulous patients with mandibular overdentures: a 10-year retrospective review of patients from a previously conducted 1-year cohort study. Int J Oral Maxillofac Implants 2019;34(1):169-178. DOI: 10.11607/jomi.6931.

16. Kaufmann R, Friedli $M$, Hug $S$, et al. Removable dentures with implant support in strategic positions followed for up to 8 years. Int J Prosthodont 2009;22(3):233-241. PMID: 19548404.

17. Preciado A, Del Río J, Suárez-García MJ, et al. Differences in impact of patient and prosthetic characteristics on oral health-related quality of life among implant-retained overdenture wearers. J Dent 2012;40(10):857-865. DOI: 10.1016/j.jdent.2012.07.006.

18. Kronström M, Widbom C, Soderfeldt B. Patient evaluation after treatment with maxillary implant-supported overdentures. Clin Implant Dent Relat Res 2006;8(1):39-43. DOI: 10.2310/j.6480.2005. 00029.x.

19. Karbach J, Hartmann S, Jahn-Eimermacher A, et al. Oral health-related quality of life in edentulous patients with two- vs four-locatorretained mandibular overdentures: a prospective, randomized, crossover study. Int J Oral Maxillofac Implants 2015;30(5):1143-1148. DOI: 10.11607/jomi.3987.

20. Cune $M$, van Kampen $F$, van der Bilt $A$, et al. Patient satisfaction and preference with magnet, bar-clip, and ball-socket retained mandibular implant overdentures: a cross-over clinical trial. Int J Prosthodont 2005;18(2):99-105. PMID: 15889656.

21. Gonçalves F, Campestrini VLL, Rigo-Rodrigues MA, et al. Effect of the attachment system on the biomechanical and clinical performance of overdentures: a systematic review. J Prosthet Dent 2020;123(4): 589-594. DOI: 10.1016/j.prosdent.2019.03.024.

22. Dudley J. The 2-implant maxillary overdenture: a clinical report. J Prosthet Dent 2014;112(2):104-107.DOI: 10.1016/j.prosdent.2013.06.025. 